\title{
Electronic commerce contribution to the SME performance in manufacturing firms: A structural equation model
}

\section{Contribución del comercio electrónico al desempeño de las PyMEs industriales: un modelo estructural}

\author{
María Verónica Alderete* \\ Instituto de Investigaciones Económicas y Sociales del Sur (IIESS), Universidad Nacional de Sur- CONICET; \\ Departamento de Economía, Universidad Nacional del Sur, Argentina
}

Received February 15, 2018; accepted November 13, 2018

Available online July 30, 2019

\begin{abstract}
The role Information and Communication Technologies (ICT) play in achieving a better organizational performance still needs further analysis among small and medium sized enterprises (SME) from developing countries. This study aims to extend the empirical literature on the relationship between ICT, electronic commerce and SME performance in developing countries. To achieve this goal, we employ a sample of 87 manufacturing firms from the city of Bahía Blanca, Argentina in the year 2015. By estimating a structural equation model, we obtain that electronic commerce adoption has a positive and significant influence on SME sales which is reinforced by the level of ICT use. Other organizational factors such as firm size and public programs explain performance, but are not significant predictors of the electronic commerce adoption.
\end{abstract}

JEL code: $\mathrm{L} 8, \mathrm{M} 15, \mathrm{O} 33$

Keywords: Electronic commerce; ICT use; SME; Developing countries

*Corresponding author.

E-mail address: mvalderete@iiess-conicet.gob.ar (M.V. Alderete).

Peer Review under the responsibility of Universidad Nacional Autónoma de México. 


\section{Resumen}

El rol que juegan las Tecnologías de la Información y comunicación (TIC) para lograr un mejor desempeño organizacional aún requiere de un análisis más profundo entre las pequeñas y medianas empresas (PyMEs) de los países en desarrollo. Este estudio pretende ampliar la literatura empírica sobre la relación entre TIC, comercio electrónico y desempeño de las PyMEs en países en desarrollo. Para alcanzar este objetivo, utilizamos una muestra de 87 empresas manufactureras de la ciudad de Bahia Blanca, Argentina correspondiente al año 2015. Mediante la estimación de un Modelo de ecuación estructura, se obtiene que la adopción del comercio electrónico posee una influencia positiva y significativa en las ventas de las PyMEs la cual es potenciada por el nivel de uso de las TIC. Otros factores organizacionales tales como el tamaño de la empresa y los programas públicos explican el desempeño, pero no son predictores significativos de la adopción del comercio electrónico.

Código JEL: L8, M15, O33

Palabras clave: Comercio electrónico, Uso de las TIC, PyMEs, Países en desarrollo

\section{Introduction}

Globalization and the increasing complexity of production processes have changed operations' management leading to a new challenge for small and medium sized enterprises (SME). Most studies argue that Information and Communication Technologies (ICT) effect on productivity is indeed positive and significant (Liao et al., 2016; Corrado et al., 2017). In this context, ICT are critical for firm success.

Based on the Resource Based View theory, competitiveness is associated with the firm's possession of different resources (Barney, 2001; Wernelfelt, 1984). As resources become scarce, the firm can achieve sustainable competitive advantages by using them. In this vein, ICT investments are relevant per se, because of the operative advantages related to ICT use, and due to complementarities with intangible assets such as human capital, expertise and organizational capital (Taher, 2012; Rivard et al., 2006). In particular, electronic commerce (e-commerce) becomes a competitive strategy and tool to remain competitive among SME (Yang et al., 2015; Abebe, 2014; Raymond et al., 2011; Wirtz et al., 2010; Kapurubandara, 2009).

ICT adoption and implementation follows an evolutionary process and consists of different phases. Such evolutionary process depends on the firm's efforts and complementarities with organizational capabilities (Rovira, Santoleri and Stumpo, 2013). Firms gradually learn to use and exploit the technology. They make efforts to develop specific organizational competences which eventually lead to a higher maturity in ICT use and implementation. Experience 
obtain by selecting, implementing and using ICT let them achieve higher benefits (Rivas and Stumpo, 2011; Kotelnicov, 2007).

In Latin America, Internet penetration, measured as the number of users compared to total population, doubled from 20.7 per cent to 50.1 per cent between 2006 and 2014. A 76 per cent of Latin-American users of Internet have accessed to on line shops. Besides, there is a low proportion of electronic commerce business compared to retail: only a 4 per cent of the world's business to commerce (B2C) in 2013 corresponds to Latin America (CEPAL, 2015). In Argentina, online retail will represent $2.9 \%$ of retail total incomes (The Boston Consulting Group, 2012).

Although numbers are still low compared to the rest of the world, the increasing interest to study ICT use and electronic commerce in developing countries is based on their potential to create value. For instance, Internet contributes to $3.6 \%$ of GDP in developing markets in 2010 (The Boston Consulting Group, 2012). On the other side, a high percentage of SMEs are low-productivity firms and present an inadequate organizational structure. These features sum up with financial restrictions and lack of human resources impose barriers to the ITC adoption process (CEPAL, 2013).

The purpose of this paper is to analyze the impact of electronic commerce on SME performance by estimating a structural equation model based on a sample of 87 manufacturing firms. The main contribution of the study is collecting information about this relationship to increase existent literature in developing countries. There are only a few studies in the field in the emergent world. Moreover, the paper uses an econometric methodology widely use in the field.

The sample is the result of a research project aiming to characterize the industrial SME firms in Bahia Blanca. A Structural Equation Model (SEM) is estimated based on the hypothesis that the level of electronic commerce adoption will have an impact on SME's performance mediated by the level of ICT use. The paper is structured as follows. At first, we describe the theoretical framework that will support the hypothesis stated. Later on, we explain the data and methodology used to test the hypotheses. After that, results obtained are analyzed. Finally, we offer some discussion and implications of the paper.

\section{Theoretical framework}

There is a distinction between ICT access and ICT use. ICT access refers to availability of an ICT infrastructure and firm's access to ICT, while ICT use concerns to ICT intensity and usage, and ICT skills at the organizational level. Anyway, both are interrelated concepts. 
As Alderete (2016) states ICT Access has a positive and significant effect on the ICT use and skills (Hargittai, 2008; Brynjolfsson and McAfee, 2015; Spieza, 2010; Sunkel and Trucco, 2010). An adequate ICT access is a necessary condition for a proper ICT use. The poorer the ICT access conditions (lack of connectivity, shortage of computers at firm, or outdated devices), the lower the opportunities to exploit ICT will be.

ICT investments should be followed by ICT management and ICT use practices to gain a better ICT exploitation (Jones et al., 2016; Raymond et al., 2011; Chen and Wu, 2011; Raymond and Bergeron, 2008; Rivard et al., 2006; Peak et al. 2005; de Guinea et al., 2005; Premkumar, 2003). Usually small firms lack the human resources and technological resources needed for an adequate ICT use and e-commerce. Contrary to ICT access, the way activities and competences are combined with ICT use leads to specificities among the organizational paths leading to different and even unique organizations (Peirano and Suarez, 2004). ICT use and diffusion is not merely a separate interactive process that takes place in households or within and between firms, but a collective process that takes place within the territory, involving all actors that through social and economic interactions contribute to disseminate knowledge about ICT use (Billon et al, 2016).

From this new ICT paradigm emerges the electronic commerce (EC) concept. Boateng et al. (2009) defines EC as the commercial information exchange, the maintenance of commercial relationships and the operation of commercial transactions through telecommunication networks. Moreover, the Organization for Economic Cooperation and Development (OECD) offers a wider concept linking the term to the use of communication systems based on the Internet or not (fixed phone and mobile phone, interactive TV, e-mail, electronic transactions) applied to different organizational objectives such as promotion and development, marketing, management, payment systems, logistics and transport, and even legal issues (OECD, 2007). On the other side, Khurana et al. (2011) defines EC as any transaction that implies the transference of property or any transfer of rights to use goods and services. This definition includes monetary and non-monetary transactions. Several authors (Jones et al., 2016; Reuber and Fischer, 2011; Chong, 2006; Molla and Licker, 2004) have distinguished different phases of the e-commerce process from an initial phase of web site implementation, mainly informative web-sites, to more advanced phases of interaction among clients and suppliers, and social networks presence, and finally offering online transactions such as budget, reservation, orders tracking, sales, among others.

During the last years, literature has addressed the positive relationship between ICT and firms performance. By firms' performance, the literature usually considers two productivity measures at firm level: i) value added per worker and ii) sales per worker. There are also other indicators or proxies of productivity such as export orientation, competitiveness, or financial indicators, among others. Most of the studies belong to developed countries (Gër- 
guri-Rashiti et al., 2015; Lucia-Palacios et al., 2014; Bayo-Mariones et al, 2013; Cardona et al., 2013; Nurmilaakso, 2009; Aral et al., 2006; Peak et al., 2005; Brynjolfsson and Hitt, 2003; Henderson and Venkatraman, 1993), while only a few corresponds to developing countries (Cuevas and Vargas, 2016; Cortes et al., 2014; Kossai and Piget, 2014; Albarracín, Erazo and Palacios, 2014; Alderete, 2013; Alderete and Gutiérrez, 2012; Caro Encalada et al, 2011). A possible reason of this scarcity in the literature might be due to missing data on ICT in SME from developing countries. For instance, Alderete and Gutiérrez (2012) find ICT (ICT investment and use) jointly increase labor productivity in about 18 per cent in services firms from Colombia by using national data. Caro Encalada et al. (2011) find a positive impact of the use of information and communication technologies (ICT) on the hospitality industry competitiveness in the Yucatán Península. On the other side, Kossai and Piget (2014) examine the relationship between ICT use and the performance of 50 Tunisian SME, finding a significant statistical one, but using a small sample.

Moreover, much less has been written about the relationship between electronic commerce and SME performance (Chen et al., 2016; Yang et al, 2015; Abebe, 2014, Bernal García et al., 2006), and especially in developing countries (Migdadi et al., 2016; Figueroa-González, 2015). Among developed countries studies, Chen et al. (2016) contribute to the theory on the resource-based view and its implications on e-business organizational performance of SME. The authors study the effect of an industry-specific web portal on textile SMEs organizational performance. Besides, Yang et al (2015) use the Resource Based View theoretical support to demonstrate that e-commerce readiness enhances firm performance. The authors suggest that more sophisticated e-commerce websites lead to better performances from a sample of British SME. Similarly, Abebe (2014) finds a positive relationship between e-commerce adoption and performance of SME. Based on a sample of 55 manufacturing and services firms from Texas, USA and by using a multiple regression analysis, he states SMEs that adopt e-commerce have statistically a higher sales growth rate than those who do not.

Bernal García et al. (2006) shows the probability that a firm performs electronic commerce in the Murcia Region, Spain. By estimating a logistic regression model, results show that this probability is the highest in a services firm, whose performance objectives are cost savings, sales, competitive advantage, information searching and a better market segmentation.

In the case of developing countries, Migdadi et al. (2016) employ a structural equation modeling with data from Saudi Arabian firms to confirm that e-business implementation affects organizational performance. On the other side, Figueroa-González (2015) finds a positive relationship between e-commerce use and performance in SME in Mexico by using contingency tables.

In Argentina, recent papers have studied the determinants of e-commerce adoption (Jones et al, 2016; Jones et al, 2013). Although these studies refer to e-commerce as an organizational 
performance per se, they do not relate e-commerce to SME performance based on sales. Jones et al (2016) analyzes the determinants of electronic commerce adoption (ACE in Spanish initials) in micro, small and medium enterprises in the services and commerce sectors from Córdoba, Argentina. ACE is the main dependent variable whose level is mainly and positively associated with the management systems and strategies of the firm. Organizational factors (internal and external) have a direct impact on those systems and strategies, and therefore are indirectly affecting ACE.

However, a successful adoption of any information technology (such as e-commerce) depends on user acceptance and actual usage of the system (DeLone and McLean, 2003). Many authors have analyzed the critical role complementary resources play to achieve a positive ICT impact on labor productivity (Tarature and Gatautis, 2014; Aral et al., 2006; Arvanitis, 2005; Brynjolffson and Hitt, 2003; Bresnahan et al, 2002).

Scafarto (2016) examines the relationship between intellectual capital (which includes human capital) and firm performance in the agribusiness industry. Based on a sample of 18 agribusinesses over the period 2010-2014, the author shows there is a significant effect of human capital to performance and he stresses complementarity between human and innovation capital. On the other side, Backman (2013) analyses the relevance of human capital for firm productivity by distinguishing between human capital inside and outside of the firm. The author estimates a multilevel model (industry and municipal level) for the business service sector in Sweden. Moreover, Arvanitis (2005) states that ICT together with human capital are key determinants of efficiency and firm performance.

On the other side, Tarature and Gatautis (2014) examine the potential direct and indirect effects of ICT on SME performance. For best performances, firms should align ICT investments with internal capabilities and organizational processes. In this sense, ICT impact on the improvement of external and internal communication. ICT, for instance web sites, can change the business structure and ways of communication of the firm. A proper web site can promote new communication channels between firms and their suppliers or clients. These changes can lead to productivity effects among organizations, in particular firms.

In respect to the relationship between firm networks and performance, cooperation emerges as a strategy to overcome SME weaknesses such as limited access to foreign or external markets, limited access to financing and lack of technological breakthrough. Hence, cooperation among firms turns into a strategy to promote firms competitiveness (Alderete, 2011). From the theory of clubs approach, firms share common resources for instance by using an impure public good (Alderete, 2015). From the transaction cost theory (Williamson, 1981), networks are instruments to reduce uncertainty, risk and inefficiency among firms transactions. On the other side, the resource based view of the firm (Prahalad and Hamel, 1990; Barney, 2001; Dyer and Singh, 1998) dominates the literature on strategic management and considers the 
firm as a set of resources and capabilities. Therefore, networks are one of the ways to reach those resources and capabilities external to the firm but internal to the network. More recently, Cai and Szeidl (2017) study the effect of Chinese business networks on firm performance, and find that networking increases firm revenue by $8.1 \%$, as well as increases other outcomes such as profits, inputs, among others. Stam et al. (2014) analysis the impact of entrepreneurs' social capital on small firm performance and finds a positive and significant link.

Lastly, there is recent evidence of the impact of public support on small firm productivity (Cin et al.2017; Huergo et al. 2016; Crespi et al., 2015). The main argument for government intervention through promotion policies is to correct market failures associated to the large costs of some productive activities such as R\&D or technological development. This policy intervention emerged initially in the United Kingdom as a way of stimulating declining urban industrial activity through tax abatements and reductions in regulation (Rubin \& Richards 1992). For instance, Cin et al. (2017) examines the impact of public R\&D subsidy on Korean SME productivity. Based on panel data estimation, subsidies increase SME productivity. Moreover, Huergo et al. (2016) analyzes the impact of public support on firm propensity to engage in R\&D. R\&D initial costs, demand characteristics and technological opportunities jointly determine innovation results and the minimum profit margin; and therefore, firms' productivity and competitive position. A similar analysis was conducted by Crespi et al (2015) for the Colombian firms. The authors find that R\&D promotion programs have increased labor productivity.

Based on the idea of complementarities, only a complete combination of co-inventions could generate significant productivity gains, while intermediate combinations might not produce any benefits (Bresnahan et al, 2002). A higher ICT use among employees produces an additional effect on productivity than ICT investments alone (Franklin et al., 2008).

Therefore, it seems important to analyze the relationship between electronic commerce, ICT use and SME performance in developing countries. This paper provides some contribution to this goal, by analyzing SME from Bahía Blanca, Argentina.

\section{Methodology}

This study uses information from the city of Bahía Blanca, in Buenos Aires province, Argentine. Database corresponds to the year 2015 from interviews made to 87 industrial firms ${ }^{1}$.

\footnotetext{
${ }^{1}$ Database derived from field interviews with small business directors and was elaborated under the Research Project "Innovation, collective action and territorial development planning in the South West". Department of Economics, Universidad Nacional del Sur.
} 
According to information from the 2005 Economic Census, Bahía Blanca concentrated 674 industrial firms, with 99\% SME. More updated data from CREEBA ${ }^{2}$ suggest there were 832 industrial establishments in 2012. Based on this information, a 87-firms sample is statistically correct (with a sample error of $10 \%$ at the $95 \%$ confidence level).

The sample was built based on the natural stratification or production specialization of the total number of firms ${ }^{3}$. It collects information on different characteristics of the firm: socio-cultural characteristics of the owner, structural characteristics of the firm (such as relationships with suppliers, clients and between firms), and the market and environmental characteristics.

Firms are classified based on their size, that is, the total number of employees. Classification by size follows a widely-used criterion: Micro-firm (1 to 10 employees), Small (11 to 50 employees) and Medium (more than 50 employees and less than 200). By analyzing the frequency of firms per size we obtain that most of the firms are Small (58\%), followed by micro-firms (36\%), and Medium (6\%). The sample includes firms with different sizes, levels of productive specialization and; therefore, different degrees of complexity in terms of products and processes.

We use Structural Equation Modelling (SEM) to test the relationship between e-commerce adoption and SME performance. There are many statistical packages being developed to analyse SEM. Among them are Lisrell, AMOS, M-plus, EQS, and SAS, just to mention a few. In the case of the present paper, we use STATA 14 to perform the estimations.

Esposito (2009) posits that Structural Equation Modeling (SEM) consists of two types known as the Variance Based Structural Equation Modeling (VB-SEM) and the Covariance Based Structural Equation Modeling (CB-SEM). These two packages have great difference in terms of their statistical approaches namely the non-parametric testing and the parametric testing, the objective of the study namely exploratory and confirmatory, and more importantly the algorithm employed namely Generalized Least Square (GLE) and Maximum Likelihood Estimator (MLE).

CB-SEM is SEM based on the covariance matrix, while PLS (Partial Least Square) is SEM based on the variance matrix (VB-SEM). CB-SEM objective is to test theory, confirm the theory based on data. Parameters are estimated so that the difference between the theoretical covariance matrix and the estimated covariance matrix (based on data) is minimized (Hair et al., 2011). On the other side, PLS-SEM objective is to develop a theory based on the emerging relationships. Thus, it is a more exploratory model. PLS objective is similar to a multiple regression analysis, whose objective is maximizing the explained variance of the dependent constructs.

2 http://www.creebba.org.ar/main/index.php?

3 The number of firms interviewed by industry were: 27 Food and Beverage, 4 Clothing and Textile, 11 Wood , 8 Paper, Editorials and Print, 6 Chemistry, 5 Non-metal minerals, 9 Basic Metals and 5 Machines, Equipments and Vehicles, 6 industrial services, 3 commercialization, 3 others. 
STATA software only uses CB-SEM (Bernardes do Nascimento and da Silva Macedo, 2016). In CB-SEM, goodness of fit measures emerge due to the discrepancy between the empirical and theoretical covariance matrix (Hair et al., 2009), while PLS-SEM originates from the discrepancy between the observed values and/or the dependent latent variables and the values estimated by the model (Hair et al., 2011). Therefore, by using PLS-SEM researchers depend on measures or indicators of the predictive capacity of the model to judge the quality or goodness of fit of the model, such as reliability, explained variance, among others; which is not needed in CB-SEM models (Henseler et al., 2009).

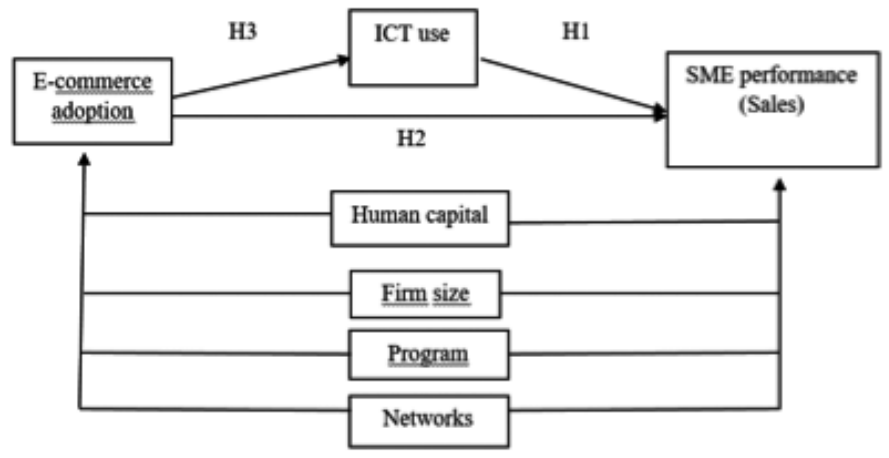

Figure 1 shows the causal relationships to be tested.

Figure 1. Theoretical model of relationship between e-commerce adoption and SME performance Source: Own elaboration

The structural model is compound of three structural equations as there are three endogenous variables: E-commerce adoption, ICT use, and SME performance.

\section{Endogenous variables}

\section{ICT use:}

The aim of this procedure is to develop an instrument for measuring ICT use for manufacturing companies from Bahía Blanca. To achieve such a goal, a set of items for measuring ICT use constructs had to be well developed. Items included are based on a thorough review of the information technology literature, and mainly on Alderete's $(2011,2009)$ questionnaire, and 
INDEC (2008). ICT use is a variable obtained from a factorial analysis among a set of ICT use indicators (Table 1). Firms were asked to provide information about the kind of activities performed by using ICT, from collecting information from the market to paying taxes.

Since we have built ICT use as a construct variable by using factor analysis, we show the reliability statistics of it. Cronbach's Alpha provides evidence of reliability and justifies the internal reliability of the scales (Hair, 2010). By using SPSS software, we obtain a Cronbach's alfa of 0.756 which confirms the reliability of the scales.

Table 1

Communalities from factor analysis among ICT use indicators

\begin{tabular}{lcccc} 
& $\mathrm{N}$ & \% colum answers & initial & Communalities \\
\hline $\begin{array}{l}\text { Collect information from } \\
\text { the market/sector }\end{array}$ & 37 & $48.1 \%$ & 1.000 & .582 \\
\hline $\begin{array}{l}\text { Contact with clients already } \\
\text { known }\end{array}$ & 67 & $87.0 \%$ & 1.000 & .810 \\
\hline $\begin{array}{l}\text { Contact with potential } \\
\text { clients }\end{array}$ & 41 & $53.2 \%$ & 1.000 & .604 \\
\hline $\begin{array}{l}\text { Contact with already known } \\
\text { suppliers }\end{array}$ & 65 & $84.4 \%$ & 1.000 & .591 \\
\hline $\begin{array}{l}\text { Contact with potential } \\
\text { suppliers }\end{array}$ & 41 & $53.2 \%$ & 1.000 & .393 \\
\hline $\begin{array}{l}\text { Buy inputs on line } \\
\text { Commercialization of pro- } \\
\text { ducts }\end{array}$ & 35 & $45.5 \%$ & 1.000 & .510 \\
\hline $\begin{array}{l}\text { Communication with go- } \\
\text { vernment }\end{array}$ & 20 & $39.0 \%$ & 1.000 & .644 \\
\hline $\begin{array}{l}\text { Banking and financial ser- } \\
\text { vices }\end{array}$ & 54 & $26.0 \%$ & 1.000 & .615 \\
\hline $\begin{array}{l}\text { Get Post sale services from } \\
\text { suppliers }\end{array}$ & 11 & $70.1 \%$ & 1.000 & .709 \\
\hline $\begin{array}{l}\text { Offer post sale services to } \\
\text { clients }\end{array}$ & 12 & $14.3 \%$ & 1.000 & \\
\hline $\begin{array}{l}\text { Payment of taxes } \\
\text { Others }\end{array}$ & 37 & $15.6 \%$ & & \\
\hline \begin{tabular}{l} 
Total \\
\hline
\end{tabular} & $78.1 \%$ & & \\
\hline
\end{tabular}

Source: Own elaboration by using SPSS. 
Table 1 shows communalities from each ICT use indicator obtained through Component Principal Analysis. We observe that one indicator, buying inputs online, is not relevant for explaining the variance (since communality is lower than 0.4 ).

Afterwards, we build a composite indicator of ICT use by using the factors obtained through the extraction method. Table 2 reports the first four factors which explain nearly 65 per cent of the variance.

Table 2

Variance explained of ICT use

\begin{tabular}{ccccccc}
\hline & \multicolumn{3}{c}{ Initial eigenvalues } & \multicolumn{2}{c}{ Extraction sums of squared loadings } \\
Component & Total & \% of total variance & cumulative $\%$ & Total & \% of variance & cumulative \% \\
1 & 3.579 & 29.826 & 29.826 & 3.579 & 29.826 & 29.826 \\
\hline 2 & 1.672 & 13.930 & 43.756 & 1.672 & 13.930 & 43.756 \\
\hline 3 & 1.438 & 11.987 & 55.743 & 1.438 & 11.987 & 55.743 \\
\hline 4 & 1.047 & 8.726 & 64.470 & 1.047 & 8.726 & 64.470 \\
\hline
\end{tabular}

Source: Own elaboration

To build the ICT use index, we calculate the weighted sum of these four factors, where weights correspond to the proportion of variance of each factor related to total variance. The average ICT use index obtained is 0.49. As we can see in Figure 1, ICT use is also an independent variable of SME performance.

The main hypothesis related to ICT use is:

Hypothesis 1: ICT use has a direct impact on SME performance.

\section{SME performance:}

There are different measures of performance: sales per worker, aggregate value per worker, exports, innovation, and so on. Choosing one indicator or another depends on data availability or previous findings. For instance, Criscuolo and Waldron (2003) find electronic commerce have a larger impact on the aggregate value than on sales. In this paper, we use the variable sales, which is an ordinal variable with 4 categories based on the amount of sales per year: 1 (less than 115 thousand dollars), 2 (between 115 and 656 thousand dollars), 3 (between 656 and 5235 thousand dollars), and 4 (more than 5235 thousand dollars). This rank is based on the SME classification for industrial firms published by the SME Secretary 21/2010 resolu- 
tion in Argentina. By asking firms to choose their corresponding category of sales, we avoid missing data (since firms are reluctant to provide information about specific amount of sales, especially in developing countries).

The main hypotheses related to SME performance are:

Hypothesis 1: ICT use has a positive impact on SME performance.

Hypothesis 2: E-commerce adoption has a direct impact on SME performance.

\section{Electronic Commerce adoption (ACE):}

On the other side, ACE is an ordinal variable which is based on Jones et al (2016) and Molla (2005). It has four possible values (Table 3): 0 , if the firm does not have a web site; 1 if the firm has a static e-commerce (publishing basic information of the firm on the web site without any interaction); 2 if the firm has an interactive e-commerce, meaning that firm accepts queries, e-mail and form entry from users, and 3 if the firm achieves a transactive ecommerce, that is selling and purchasing products online.

The main hypothesis related to ACE is:

Hypothesis 3: E-commerce adoption has a direct impact on ICT use.

In Table 3, we provide information about the number of firms in each e-commerce category.

Table 3

Frequency distribution of firms in each e-commerce category

\begin{tabular}{cccc}
\hline Level of ACE & Frequency & Percentage & Accumulated percentage \\
\hline 0 None & 35 & 40,2 & 40,2 \\
\hline 1 informative & 28 & 32,2 & 72,4 \\
\hline 2 interactive & 23 & 26,4 & 98,9 \\
\hline 3 transactive & 1 & 1,1 & 100,0 \\
\hline Total & 87 & 100,0 & \\
\hline
\end{tabular}

Source: Own elaboration

More than a half of the firms in the sample have a website (nearly 60 per cent). Besides, most firms that have a web site to commercialize their products do not have a shopping cart. Contact with clients is mainly through online entry form to receive consultations. There is only one firm with a shopping cart from the wood and furniture industry. 
Moreover, we could notice that many firms had mixed up social network presence with website presence. Many of the firms without their own website but having a facebook profile had answered having a website. Therefore, we check this information provided by the firms before doing the analysis.

As we can see in figure 1, ACE is also an independent variable both in the ICT use and SME performance structural equations.

By adding both electronic commerce adoption and ICT use to the model, we include measures of ICT investment and ICT uses. Since ICT impact on productivity is a complex process, by including only one ICT indicator we would over o sub-estimate their real impact.

\section{Exogenous variables}

Firm size: The size of the firm is measured by the total number of employees, both permanent and transitory. The survey asks each firm to provide information about the number of employees. Based on the literature, we suppose that the larger the size of the firm, the higher the performance will be. A widely concern classification of firm size in the literature states that: micro-firms (between 1 to 10 employees), small (between 10 and 50 employees), medium (between 51 and 150 employees), and large (more than 150 employees). Table A1 in Appendix provide the descriptive statistics.

Human Capital: the percentage of employees with a tertiary and/or university degree level (either complete or incomplete).

Program: a binary variable that indicates whether the firm has ever participated of any public program or been awarded with a program.

Network: a binary variable that indicates if the firm has built any agreement with other firms from the same industry or others. For instance, export consortium, buying consortium, research and development consortium, cooperatives and transitory unions.

\section{Results}

Contrary to most SEM models, we do not estimate latent variables. All the variables in the model are observed. For instance, we add ICT use as an exogenous variable instead of building a latent variable because of the scarce number of observations. Therefore, no measurement models are provided in this study.

Following, we examine the goodness of fit of the structural model (Table 4). Based on the Chi Square test, the structural equation model estimated can explain the theoretical model. 
To achieve an adequate goodness of fit, Chi square values should be near zero. In this case, Chi square is 2.26 with a p-value of 0.68 . Hence, we cannot reject the hypothesis of a perfect correspondence between the estimated matrix and the observations matrix.

Moreover, to offer a more sensible approach than the test of exact fit, we use the Root Mean Square Error of Approximation (RMSEA). If RMSEA is lower than 0.05 and does not exceed the lower bound of the 90 percent confidence interval, the model fit is good (Steiger, 1990). Since RMSEA is zero, we can determine the model fits well.

On the other side, the Root Mean Square Residual index (RMR) is an overall measure of bad fit based on the fitted residuals (]öreskog and Sörbom, 1981). Since the fitted residuals are scale dependent, depending on the sizes of the variances and covariances of observed variables, the Standard RMR (SRMR) is introduced. A value less than 0.05 indicates a good fit (Hu and Bentler, 1995).

Table 4

Goodness of fit of the structural model

\begin{tabular}{lll}
\hline Statistic & Value & Description \\
\hline Likelihood Ratio & & \\
\hline Chi square_ms(4) & 2.261 & model vs. saturated \\
\hline $\mathrm{p}>$ chi square & 0.688 & baseline vs. saturated \\
\hline Chi square_bs(45) & 78.182 & \\
\hline $\mathrm{p}>$ chi square & 0.000 & Root Mean Square Error of Approximation \\
\hline Population Error & & \\
\hline RMSEA & 0.000 & \\
\hline $90 \%$ CI, lowerbound & 0.000 & RMSEA probability<=0.05 \\
\hline Pclose & 0.142 & Standardized root mean squared residual \\
\hline Size of residuals SRMR & 0.749 & \\
\hline
\end{tabular}

Source: Own elaboration based on Stata 14.

After checking the goodness of fit of the model, we analyze the structural model (Table 5 and Figure 2). Based on Table 5, ACE positively affects the ICT use ( $\beta=0.0978$ ) (hypothesis 3). Advanced levels of electronic commerce adoption imply the firm is provided with more advanced website features and content. As the ICT infrastructure is complete and more complex, firms can exploit better opportunities related to different ICT uses. For instance, Interactive e-commerce enhances the relationship and contact with already known and po- 
tential clients and suppliers. On the other side, firms with static e-commerce are not able to manage communications.

Besides, ICT use directly impacts on SME sales (hypothesis 1). ACE significantly and positively explains sales $(\beta=0.7452)$. Hence, firms with a higher level of electronic commerce have more chances to commercialize their products and contact potential clients, which finally lead to a better performance. Since ICT use positively explains sales, ICT use mediates the relationship between electronic commerce level and performance (hypothesis 2).

Therefore, ACE has a direct effect on Sales $(\beta=0.2417)$ and an indirect effect mediated by ICT use $(0.072=0.0978 * 0.7452)$. Hence, ACE's total effect is the sum of the direct and indirect effects (0.072).

Moreover, the organizational and external factors of a firm are significant determinants of Sales, but they are not significant factors of ACE. Among these variables, human capital and network are not significant in any structural equation. Therefore, education and networking do affect neither electronic commerce adoption nor SME performance.

Table 5

Structural models

\begin{tabular}{lccc}
\hline Variable & Structural equation ICT use & Structural equation & Structural equation Sales \\
ACE & $.0978284 * * *$ & ACE & $.2417263 * * *$ \\
ICT use & $\mathrm{nc}$ & $\mathrm{nc}$ & $.7452192 * * *$ \\
Human capital & $\mathrm{nc}$ & $\mathrm{nc}$ & -.0033578 \\
Firm size & $\mathrm{nc}$ & .0058168 & $.0229282 * * *$ \\
Program & $\mathrm{Nc}$ & -.0049497 & $.3068007 * *$ \\
Network & $\mathrm{nc}$ & .0186114 & -.1591083 \\
Constant & $.4108807 * * *$ & -.0924008 & $.7251304 * * *$ \\
\hline
\end{tabular}

Source: Own elaboration.

Notes: nc means do not correspond; *** significant at $1 \%$ level. 


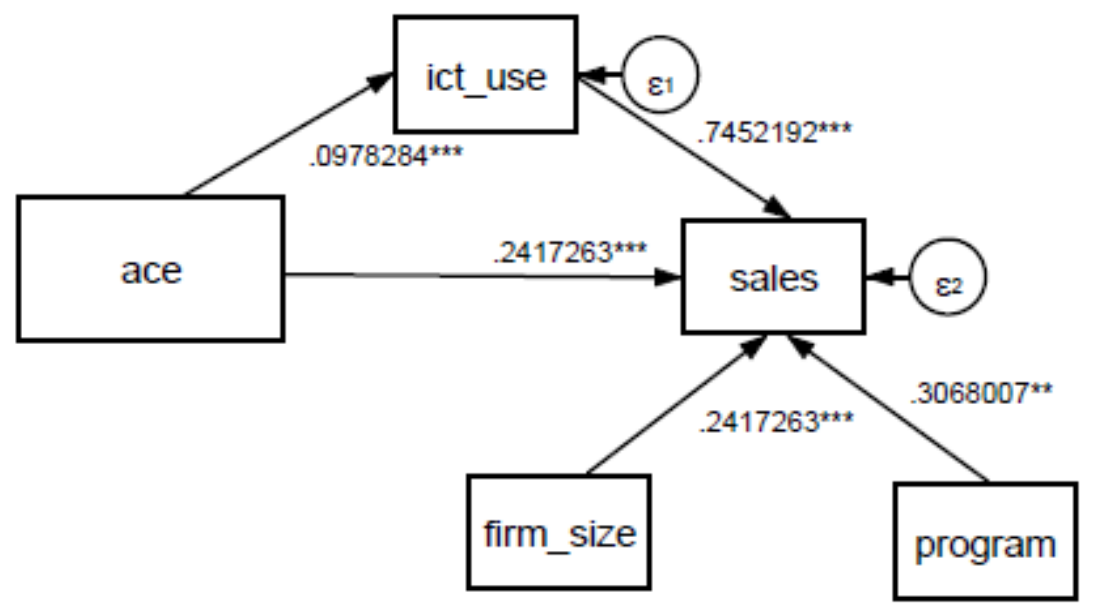

Figure 2. Results obtained

Source: Own elaboration based on Stata 14.

Note: only significant relationships are presented. $* * *, * *$ significant at $1 \%$ and $5 \%$ levels.

\section{Conclusions}

In recent years, firms have gradually adopted ICT as they become aware of their several benefits. Although the new ICT paradigm promises many advantages in terms of competitiveness, empirical evidence on the relationship between ICT and SME performance is still scarce in developing countries, moreover, in respect to e-commerce adoption.

This research has shown, on the one hand, that ICT use has a direct impact on SME performance. This result confirms previous findings in developing countries (Cuevas and Vargas, 2016; Kossai and Piget, 2014; Cortes et al., 204; Alderete, 2013; Alderete and Gutierrez, 2012) in the Tunisian, Mexican, Argentinean and Colombian SMEs.

On the other hand, the main contribution of this paper is to explore the relationship between the degrees of electronic commerce and SME performance, a recent field of research that deserves more study. Results obtained show that firms with more sophisticated websites capable of doing e-commerce achieve larger sales than SME with zero or basic websites. In this sense, our paper follows Migdadi et al. (2016) in Saudi Arabia and Figueroa González (2015) in Mexico. 
E-commerce builds competitive advantages as firms can access and contact with potential clients, not only from external markets, but also access to new domestic clients. Moreover, firms can provide more services to existent clients and suppliers.

Similar to Jones et al. (2016), non-ICT organizational and external factors do not have a statically significant effect on electronic commerce adoption. However, these results are different from Migdadi (2016) who find human capital positively affects e-commerce. One of the reasons is the author uses the construct organizational learning capabilities. Therefore, the significance of human capital could emerge from employing a more complex variable. On the contrary, our study does not provide information about capabilities but only about the proportion of employees with a tertiary and/or university degree. Only nearly 40 per cent of the firms under study employ qualified workers; and on average 13 per cent of employees are qualified. This low fraction of qualified workers is also present in previous studies (Jones et al., 2016; Jones et al., 2013). Therefore, human capital unless being a critical factor in developed countries studies (Chen et al., 2016; Yang et al, 2015; Abebe, 2014), is not crucial to explain more sophisticated e-commerce levels in developing countries. As jones et al (2016) address, ICT strategy and management play a more significant role in the relationship between organizational factors and organizational performance. We have also estimated the model including employees' training (as a proxy of learning capabilities) as an independent variable to explain ACE, with non-significant results.

On the other side, some organizational factors have a positive incidence on firms' performance (measured by sales). Larger firms (in our sample medium is the largest size) can achieve a better performance than micro-enterprises. Moreover, firms that are benefit by some public program become more productive than the rest.

Practical implications refer to the need to provide SME incentives to implement well developed websites. These incentives are critical since ICT infrastructure in developing countries is not accessible and affordable as in developed countries. These incentives could emerge from public programs to social partners, for instance large suppliers already employing business to business channels. By doing so, SME are capable of performing e-commerce. The effects of higher levels of e-commerce adoption on SME performance will depend on other organizational factors. In particular, the type of activities performs by using ICT will enforce the impact of e-commerce adoption on the firm performance. If a more sophisticated website is provided, but the firm only uses internet for collecting information from the website, the results obtained in terms of sales will be poor.

Some limitations of the paper arise from the lack of information about managerial practices from the survey. Besides, it would be interesting to identify the effect of managerial perceptions on e-commerce adoption and of managerial decisions on SME performance. In this sense, this study builds the model of SME performance based on objective data, instead of perception or intention variables which refers to qualitative data. 


\section{References}

Abebe, M. (2014). Electronic commerce adoption, entrepreneurial orientation and small- and medium-sized enterprise (SME) performance. Journal of Small Business and Enterprise Development, 21 (1), 100-116. http://dx.doi.org/10.1108/JSBED-10-2013-0145

Albarracín, J. G., Erazo, S. C. and Palacios, F. C. (2014). Influencia de las tecnologías de la información y comunicación en el rendimiento de las micro, pequeñas y medianas empresas colombianas. Estudios Gerenciales, 30(133), 364-365. https://doi.org/10.1016/j.estger.2014.06.006

Alderete, M.V and Gutiérrez, L.H. (2012). TIC y Productividad en las industrias de servicios en Colombia. Lecturas de Economía, 77, 163-188.

Alderete, M.V. (2011). Networks versus ICT Use: the case of SME from Bahía Blanca, Buenos Aires, Argentine. Journal of Information Systems and Technology Management, 8 (2), 291-314. http:// dx.doi.org/10.1590/S1807-17752011000200002

Alderete, M.V. (2015). Redes de pymes: una visión desde las teorías de club y de equipo. Revista de Economía Institucional 17 (32), 317-348. https://doi.org/10.18601/01245996.v17n32.11

Alderete, M.V. (2016). Examining the ICT access effect on socio-economic development: the moderating role of ICT use and skills. Information Technology for Development, 23 (1), 42-58. https:// doi.org/10.1080/02681102.2016.1238807

Aral, S; Brynjolfsson, E and Wu, D. (2006). Which came first, IT or productivity? The virtuous cycle of investment and use in enterprise systems. Twenty Seventh International Conference on Information Systems, Milwaukee 2006.

Arvanitis. S. (2005). Computerization. Workplace Organization. Skilled Labor and Firm Productivity: Evidence for the Swiss Business Sector. Economics of Innovation and New Technology, 14(4), 225-249. https://doi.org/10.1080/1043859042000226257

Backman, M. (2013). Human capital in firms and regions: impact on firm productivity. Papers in regional science, 93 (3), 557-575.

Barney, J. B. (2001). Resource-based theories of competitive advantage: A ten-year retrospective on the resource-based view. Journal of management, 27(6), 643-650. https://doi.org/10.1016/S01492063(01)00115-5

Bayo-Moriones, A., Billón, M. and Lera-López,F. (2013). Perceived performance effects of ICT in manufacturing SMEs. Industrial Management \& Data Systems, 113 (1), 117-135. https://doi. org/10.1108/02635571311289700.

Bernal García, J.J. and Martínez María-Dolores, S. María and Sánchez García, J. F., (2006). Study of the potentiality of the electronic commerce in the Region of Murcia by means of a model of logistic regression/Estudio de la Potencialidad del Comercio Electrónico en la Región de Murcia medi. Estudios de Economía Aplicada, 24, 499-529. 
Bernardes do Nacimento, J.C. and da Silva Macedo, M.A. (2016). Structural equation models using partial least squares: an example of the application of SmartPLS in accounting research. REPeC - Revista de Educação e Pesquisa em Contabilidade, 10 (3), 282-305.

Billon, M., Lera-Lopez, F., \& Marco, R. (2016). ICT use by households and firms in the EU: links and determinants from a multivariate perspective. Review of World Economics, 152(4), 629-654.

Boateng, R., Molla, A. y Heeks, R. (2009). E-Commerce in developing economies: a review of theoretical frameworks and approaches. In K. Rouibah, O.E. Khalil, \& A.E. Hassanien (eds.). Emerging markets and e-commerce in developing economies (pp. 1-56). El Cairo, Egipto: Universidad del Cairo.

Bresnahan, T.F., Brynjolfsson, E. and L.M. Hitt (2002). Information technology, workplaceorganization, and the demand for skilled labor: firm-level evidence. The Quarterly Journal of Economics, 117, 339-376. https://doi.org/10.3386/w7136

Brynjolfsson E. and Hitt L. (2003). Computing Productivity: Firm-Level Evidence. Review of Economics and Statistics, 85, 793-808. https://doi.org/10.1162/003465303772815736

Brynjolfsson, E. and Mc Afee, A. (2015). The second Machine Age. New York: W.W. Norton \& Company.

Cai, J. and Szeidt, A. (2017). Interfirm relationships and business performance. The Quarterly journal of economics, 133 (3), 1229-1282. https://doi.org/10.3386/w22951

Cardona, M., Kretschmer, T. and Strobel, T. (2013). ICT and productivity: conclusions from the empirical literature. Information Economics and Policy, 25 (3), 109-125. https://doi.org/10.1016/j. infoecopol.2012.12.002

Caro Encalada, M. J.; Leyva Morales, C. E. and Vela Manzanilla, R. (2011). Quality of the information technology and competitiveness in the Yucatán Península hotels. Contaduría y Administración (235), 121-146.

CEPAL (2013). Economía digital para el cambio estructural y la igualdad (LC/L3602). Santiago de Chile, Naciones Unidas.

CEPAL (2015). La nueva revolución digital. De la internet del consume a la internet de la producción. Santiago de Chile, Naciones Unidas.

Chen, Y-Y.K., Jaw, Y-L., and Wu, B-L. (2016). Effect of digital transformation on organizational performance of SMEs: Evidence from the Taiwanese textile industry's web portal. Internet Research, 26 (1), 186-212. https://doi.org/10.1108/IntR-12-2013-0265

Chong, S. (2006). An empirical study of factors that influence the extent of deployment of electronic commerce for Small-and Medium sized enterprises in Australia. Journal of Theoretical and Applied Electronic Commerce Research, 1 (002), 45-57.

Cin, B.C; Kim, Y.J and Vonortas, N.S. (2017). The impact of public R\&D subsidy on small firm productivity: evidence from Korean SMEs. Small Business Economics 48 (2), 345-360. https://doi. org/10.1007/s11187-016-9786-X 
Corrado, C., Haskel, J. and Jona-Lasinio, C. (2017). Knowledge spillovers, ICT and productivity growth. Oxford Bulletin of Economics and Statistics, 0305-9049. https://doi.org/10.1111/obes.12171.

Crespi, G., Figal Garone, L., Maffioli, A. and Meledez, M. (2015). Long term productivity effects of public support to innovation in Colombia. Emerging markets finance and trade, 51 (1), 48-64. https:// doi.org/10.1080/1540496X.2015.998080

Criscuolo, C. and Waldron, K. (2003). E-Commerce and Productivity. Economic Trends 600, UK Office for National Statistics.

de Guinea, A.O., Kelley, H. y Hunter, M.G. (2005). Information systems effectiveness in small businesses: extending a Singaporean model in Canada. Journal of Global Information Management, 13 (3), 55-79.

DeLone, W.H and McLean, E.R. (2003). The DeLone and McLean model of informationsystems success: a ten-year update. Journal of Management Information Systems, 19 (4), 9-30.

Dyer, J., Singh, H., 1998. The relational view: cooperative strategy and sources of inter-organizational competitive advantage. Academy of Management Review 23, 660-679.

Esposito, V. V. (2009). PLS path modeling and PLS regression: A joint partial least squares component-based approach to structural equation modeling. IFCS@ GFKL-Classification as a Tool for Research (IFCS 2009).

Figueroa González, E.G. (2015). Rentabilidad y uso de comercio electrónico en las micro, pequeñas y medianas empresas del sector comercial. Revista iberoamericana para la investigación y el desarrollo educativo, 6(11), 1-24.

Gërguri-Rashiti, S., Ramadani, V., Abazi-Alili, H., Dana, L.P., and Ratten, V. (2015). ICT, innovation and firm performance: the transition economies context. Thunderbird International Business Review, 59(1), 93-102. https://doi.org/10.1002/tie.21772

Hair, J. F., Ringle, C. M., and Sarstedt, M. (2011). PLS-SEM: Indeed a silver bullet. The Journal of Marketing Theory and Practice, 19(2), 139-152. https://doi.org/10.2753/MTP1069-6679190202

Hair JF, Black WC, Babin BJ, Anderson RE. Multivariate Data Analysis. 7th Edition. New Jersey: Prentice Hall; 2010.

Henderson, J.C. and Venkatraman, N. (1993). Strategic alignment: leveraging information technology for transforming organizations. IBM Systems Journal, 32 (1), 472-484. https://doi.org/10.1147/sj.382.0472

Henseler, J., Ringle, C. M., and Sinkovics, R. R. (2009). The use of partial least squares path modeling in international marketing. Advances in international marketing, 20, 277-319. https://doi. org/10.1108/S1474-7979(2009)0000020014

Huergo, E., Trenado, M. and Ubierna, A. (2016). The impact of public support on firm propensity to engage in R\&D: Spanish experience. Technological forecasting \& social change, 113 (B), 206-219. https://doi.org/10.1016/j.techfore.2015.05.011

INDEC (2008). Utilización de Tecnologías de la Información y las Comunicaciones (TICs) en las empresas industriales argentinas. https://www.indec.gob.ar/nuevaweb/cuadros/16/tic_12_08.pdf 
Jones, C; Alderete, M.V. and Motta, J. (2013). Adopción del Comercio electrónico en Micro, Pequeñas y Medianas empresas comerciales y de servicios de Córdoba, Argentina. Cuadernos de Administración 29 (50), 49-59.

Jones, C; Motta, j. and Alderete, M.V. (2016). Gestión estratégica de Tecnologías de Información y Comunicación y adopción del comercio electrónico en MiPyMEs de Córdoba, Argentina. Estudios gerenciales, 32 (138), 4-13. https://doi.org/10.1016/j.estger.2015.12.003

Kapurubandara, M.A. (2009). A Framework to e-Transform SMEs in Developing Countries. The electronic Journal of Information Systems in developing countries 39 (3), 1-24. https://doi. org/10.1002/j.1681-4835.2009.tb00277.x

Kossai, M. and Piget, P. (2014). Adoption on information and communication technology and firm profitability: empirical evidence from Tunisian SMEs. Journal of high technology management research, 25, 9-20. https://doi.org/10.1016/j.hitech.2013.12.003

Kotelnikov, V. (2007). Small and Medium Enterprises and ICT, United Nations Development Programme - Asia-Pacific Development Information Programme (UNDP-APDIP) and Asian and Pacific Training Centre for Information and Communication Technology for Development, Bangkok.

Khurana, H., Goel, M., Singh, H., and Bhutani, L. (2011). E-Commerce: role of e-commerce in today's business. International Journal of Business Management Research, 1 (7), 454-461.

Liao, H., Wang, B., Li, B. And Weyman-Jones, T. (2016). ICT as a general-purpose technology: the productivity of ICT in the United States revisited. Information Economics and Policy, 36 10-25. https:// doi.org/10.1016/j.infoecopol.2016.05.001

Lucia-Palacios, L., Bordonaba-Juste, V., Polo-Redondo, Y. and Grúnhagen, M. (2014). Technological opportunism effects on IT adoption, intra-firm diffusion and performance: evidence from US and Spain. Journal of business research, 67, 1178-1188. https://doi.org/10.1016/j.jbusres.2013.05.004.

Migdadi, M.M., Abu Zaid, M.K., Yousif, M., Almestarihi, R. and Al-Hyari, K. (2016). An empirical assessment of the antecedents of electronic-business implementation and the resulting organizational performance. Internet Research, 26 (3), 661-688. http://dx.doi.org/10.1108/IntR-08-2014-0203

Molla, A. and Licker, P. S. (2004). eCommerce adoption in developing countries: a model and instrument. Information \& Management 424, 877-899. https://doi.org/10.1016/j.im.2004.09.002

Nurmilaakso, J. (2009). ICT solutions and labor productivity: evidence from firm-level data. Electronic Commerce Research, 9, 173-181. https://doi.org/10.1007/s 10660-009-9034-4.

OECD, (2007). Catching-up in Broadband: What will it Take? OECD, Paris

Peak, D., Guynes, C.S., and Kroon, V. (2005). Information technology alignment planning- a case study. Information and Management, 42, 635-649. https://doi.org/10.1016/j.im.2004.02.009

Peirano F. and Suárez D (2006). TICs y empresas: propuestas conceptuales para la generación de indicadores para la sociedad de la información. Journal of informations Systems and Technology Managment , 3, 2. 
Prahalad, C., and Hamel, G. (1990). The Core Competence of the Corporation. Harvard Business Review, 68, 79-91.

Premkumar, G. (2003). A meta-analysis of research on information technology implementation in small business. Journal of Organizational Computing \& Electronic Commerce, 13(2), 91-121. https:// doi.org/10.1207/S15327744JOCE1302_2

Raymond, L., Croteau, A.M. and Bergeron, F. (2011). The strategic role of IT as an antecedent to the IT sophistication and IT performance of manufacturing SMEs. International Journal on Advances in Systems and Measurement 4, 203-211.

Raymond, L. and Bergeron, F. (2008). Enabling the business strategy of SMEs through e-business capabilities: A strategic alignment perspective. Industrial Management \& Data Systems, 108(5), 577595. https://doi.org/10.1108/02635570810876723

Reuber, A. R. and Fischer, E. (2011). International entrepreneurship in internet-enabled markets. Journal of Business Venturing, 26(6), 660-679. https://doi.org/10.1016/j.jbusvent.2011.05.002

Rivard, S., Raymond, L. and Verreault, D. (2006). Resource-based view and competitive strategy: an integrated model of the contribution of information technology to firm performance. The Journal of Strategic Information Systems, 15 (1), 29-50. https://doi.org/10.1016/j.jsis.2005.06.003

Rivas D. and Stumpo G. (2011). Las TIC en el tejido productivo de América Latina. En Novick M. y Rotondo S. (Compiladores).El desafío de las TIC en Argentina. Crear capacidades para la generación de empleo, CEPAL, Santiago de Chile.

Rovira, S., Santoleri, P. and Stumpo, G. (2013). Incorporación de TIC en el sector productivo: uso y desuso de las políticas públicas para favorecer su difusión. In Sebastián Rovira and Giovanni Stumpo (comps.). Entre mitos y realidades. TIC, políticas públicas y desarrollo productivo en América Latina. Santiago de Chile, Comisión Económica para América Latina y el Caribe (CEPAL).

Rubin B, R.C. (1992). A transatlantic comparison of enterprise zone impacts: the British and American experience. Economic Development Quarterly, 6(4), 431-43. https://doi.org/10.1177/089124249200600409

Scafarto, V., Scafarto, F. R. F.(2016). Intellectual capital and firm performance in the global agribusiness industry: the moderating role of human capital. Journal of Intellectual Capital, 17 (3), 1-30. https://doi.org/10.1108/JIC-11-2015-0096

Spiezia V. (2010) Does Computer Use Increase Educational Achievements? Student-level Evidence from PISA.OECD Journal: Economic Studies. Available at: http://www1.oecd.org/eco/labour/49849896. pdf

Stam, W., Arzlanian, S. and Elfring, T. (2014). Social capital of entrepreneurs and small firm performance: a meta-analysis of contextual and methodological moderators. Journal of business venturing, 29 (1), 152-173. https://doi.org/10.1016/j.jbusvent.2013.01.002

Sunkel, G. and Trucco, D. (2010). Nuevas Tecnologías de la información y la comunicación para la educación en América Latina: riesgos y oportunidades. Serie políticas sociales 167. ECLAC. 
Taher, M. (2012). Resource-Based View theory. In Y-K- Dwivedi et al. (eds), Information Systems Theory: explaining and predicting our digital society, vol I, Integrated series in Information Systems 28, 151-163.

The Boston Consulting Group (2012). The internet economy in the G-20. The $\$ 4.2$ trillion growth opportunity. Report March 2012.https://www.bcg.com/documents/file100409.pdf

Wernerfelt, B. (1984). A resource-based view of the firm. Strategic management journal, 5(2), 171-180.

Wirtz, B.; Shilke, O., and Ullrich, S. (2010). Strategic Development of Business Models. Implications of the Web 2.0 for Creating Value on the Internet. Long Range Planning 43, (2/3), 272-290. https://doi. org/10.1016/j.lrp.2010.01.005

Yang, T., Xun, J., and He, X. (2015). British SMEs' e-commerce technological investments and firm performance: an RBV perspective. Technology analysis \& Strategic Management, 27(5), 586-603. http://dx.doi.org/10.1080/09537325.2015.1019453 


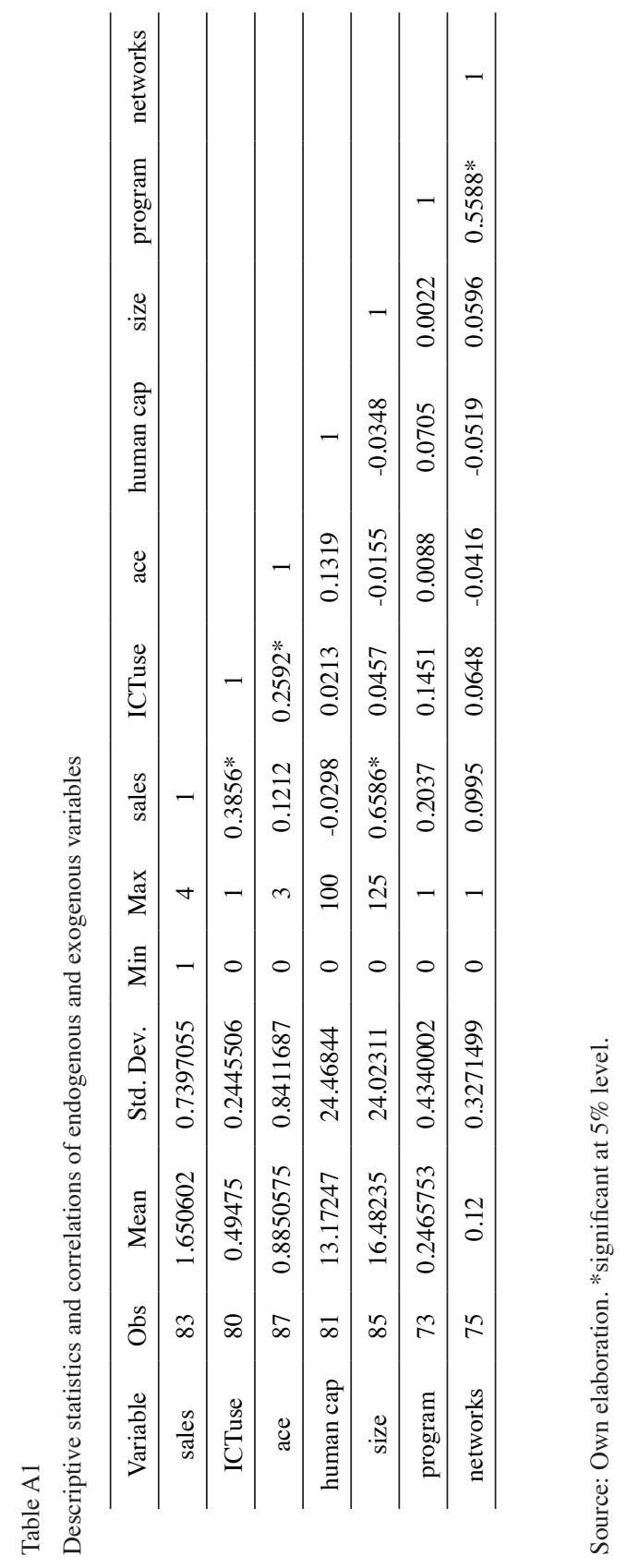

